\title{
The efficacy of the addition of short-term desmopressin to alarm therapy in the treatment of primary nocturnal enuresis
}

\author{
Cuneyt Ozden • Ozdem Levent Ozdal · Binhan Kagan Aktas • \\ Alper Ozelci · Serkan Altinova $\cdot$ Ali Memis
}

Published online: 8 April 2008

(C) Springer Science+Business Media B.V. 2008

\section{Erratum to: Int Urol Nephrol \\ DOI 10.1007/s11255-008-9355-6}

In the original article an incorrect total of 52 patients is specified for the study. The number should be 58 (30 plus 28 , as correctly specified for groups 1 and 2 , resp.). The error occurs both in the opening line of the Materials and methods section and in the corresponding paragraph of the Abstract.

The online version of the original article can be found under doi:10.1007/s11255-008-9355-6.

C. Ozden $(\bowtie) \cdot$ O. L. Ozdal · B. K. Aktas · A. Ozelci ·

S. Altinova - A. Memis

Department of Urology, Numune Education and Research

Hospital, Cevizlidere Mah. 14. Cad, Balgat 12/25,

06100 Ankara, Turkey

e-mail: cuneytozden@hotmail.com 